\title{
A STUDY ON SAW DUST WASTE NATURAL FERTILIZER AND POLLUTION FREE INDIAN RAILWAYS
}

\author{
P. Raj Kumar \\ Associate Professor, Madurai Kamaraj University, Madurai (Tamil Nadu) India \\ Email: rp878101@gmail.com, rajkumarp.p947@gmail.com
}

\begin{abstract}
The Madurai Kamaraj University is situated in Madurai town, Tamil Nadu state, India is an urban area has geographical Location of Latitude 9.941418, Longitude 78.008896 and GPS Latitude coordinates - $9^{\circ} 56^{\prime}$ ' 29. 1048 “ $N$ and Longitude $78^{\circ} 0^{\prime}$ ' 32.0256 “ $E$. The population in Madurai metropolitan town is around 14, 65,625 Lakhs (in 2011 census)-[Male-7, 33,821 Lakhs and female-7, 31,804 Lakhs]. The study of air pollution in this paper consist of two partsOne part deals with (1): The survey of Improved air quality dedicated to nation by Indian Rail Transport (98.5 percent), in outdoor air pollution control, which is done by a conversion process of electrification implemented in all rail tracks in India - and other part deals with (2): Indoor air pollution generated in a saw mill may be handled by best solid waste recycling process of compost method for agricultural usage. This study of saw dust recycling is come under the Indoor air quality engineering. The Indoor air pollution is very important because the outdoor air pollution is lower than Indoor air pollution. Also, the outdoor air is a source of supply of air to indoor environment in a house/ Industry. In general, the saw mill generates more amount of saw dust per year. The solid waste of saw dust is disposed by open firing method, creates air pollution in local atmosphere and creates lot of health problems to working people inside and surrounding living people nearby saw mill in an urban area. The saw dust mixed with (cow + goat dung) is completely converted into natural fertilizer for agriculture. This study also focus on The Indian railway introduces electrification in rail track (except Rameshwaram) in several routes and ensure air pollution free zone that is zero percentage carbon emission zone.
\end{abstract}

Key words: Timber Waste, Ground Nut Waste, Coconut Waste, Straw Waste, Carbon Zones

\section{Introduction}

Every person lives in India, have a rights to breathe clean air, pure water to drink and healthy food to eat. In this study, I find that peoples are lived in a lack of healthy environment in India. We are having Environmental laws and Forest Laws are available to control the emission of waste from an Industry. But air quality available in some of cities founded in low levels (for example: Varanasi and Delhi). The Madurai Kamaraj University is situated in Madurai town, Tamil Nadu state; India is an urban area has a geographical Location of Latitude 9.941418, Longitude 78.008896 and GPS /DMC Latitude- coordinates- 9 ${ }^{\circ}$ 56' 29. 1048 'N and GPS/DMS Longitude $-78^{\circ} 0$ ' 32.0256 'E. The population in Madurai urban area in continuously increased every year and death rate is decreased in considerable amount, due to advanced medical facility available in the town areas. The population in Madurai urban area is: 14,65,625 Lakhs (in 2011 census)-[Male-7,33,821 Lakhs and female-7,31,804 Lakhs (census 2011) ${ }^{[1]}$. In year-2021 census, the population growth will be doubled as compared with previous census 2011.

Every state in India has its own pollution control Board to control and ensure the minimum air quality standard inside and outside an Industry. The central government also monitors all the Industries indirectly in India. The duty of a pollution board is air pollution sample is taken from the Industry and analyzed. The result will be declared by comparison with previous air pollution standard data in the process and control Labs. Based on the result, the Industry is identified and issued ISO certificates to the particular company. If the air quality level is below 
the standard level, the pollution board has enough power to instruct the Industry to maintain the air quality standard. Each Industry also has its own testing lab for testing purpose in a predefined time ${ }^{[2,3]}$. A penalty may be imposed to an Industry for their ignorance on running the Industry without controlling the emission of waste to atmosphere. In India, time to time the pollution Board has given suggestions to all Industry about the pollution control activities in India. It is a routine job for the pollution control board is, to monitor and give their reports to Government higher authorities periodically. A periodic visit (schedule) is carried out by the pollution board and the Industry is continuously monitored in round the clock and maintains their air standard in particular urban area in India. The design of chimney height is one of the very important factors for a plant because which affect the air pollution control. The air pollution from an Industry leads to either short period impact or long time impact on human health related problems (skin and heart problems).

In this paper the author has tried to focusing Saw dust-solid waste disposal in new approach for small scale formers. By this process, the land automatically regains their nutrition's again and again. This study of saw dust recycling is come under the Indoor air quality engineering. In Urban side most of Saw dust, banana tree waste are dumped in one place and fired in open place. After cultivation is over in an agricultural field, in general, the banana tree waste are collected and fired in open place is general procedure followed by a small scale former. It creates air pollution in local urban areas. Each country has its own method for composting a solid waste disposal management. I selected the very low cost method for the conversion process. The Banana tree waste and saw dust was mixed with (cow dung + goat dung) certain ratio. The preparation of composting is done in a pit of pre-defined sizes ${ }^{[4,5]}$. The soil layer and waste layer are filled in alternate layer in a pit. Within few months the above items are converted into simple/ low cost fertilizer for agricultural usage with high neutrinos. This method used here for converting waste to natural fertilizer is called composting. It is one of the best methods to convert timber waste (saw dust) to agricultural fertilizer completely in a useful manner. It is also suitable for Diary firms one who produce more amount cow dung in a small period to avoid open burning method ${ }^{[6]}$.

\section{Methodology}

The Saw dust may be used for fuel directly in homes and also used in power production in some countries ${ }^{[7,8]}$. The Saw dust is purchased from a Local Saw mill at the rate of Rs. 20.0 per bag (25 kg.) is collected nearby Batalagundu urban area, which is my selected area of limitation for this paper. All the agricultural solid wastes are collected from, my own agricultural firm, in the place of Batalagundu (4 acre). The solid wastes are collected from agricultural waste on the weight basis. The sample consists of $2000 \mathrm{~kg}$. cow dung, $2000 \mathrm{~kg}$. goat dung, $200 \mathrm{~kg}$. rice straw, $500 \mathrm{~kg}$ saw dust, $200 \mathrm{~kg}$. banana tree waste, $200 \mathrm{~kg}$ coconut tree waste(leaf only) and $200 \mathrm{~kg}$ ground nut waste. The water is collected from a $(2 \times 1000)$ liter plastic tank installed nearby pit and a required plastic hose of 100 meter length also purchased from local shop at the rate of Rs.12.0 per feet. The method used here is composting method. In a short period, this gives an output of natural agricultural fertilizer from a particular solid waste by a recycling process.

\section{Study Area}

The selected urban area for my sample collection is very much close to Madurai town is Batalgundu. The cultivation in this area is mostly paddy, sugar cane, banana tree and coconut tree. Throughout the year the cultivation was takes place in a cyclic manner depends upon the water availability. In several years, the solid waste disposal is a very big problem to local farmers in these areas. So, the author has taken this task as pilot one to find out a remedy for this problem. The author used a composting method without using any microorganism. After 
composting, this product is used in agricultural purpose, for plant growth in different field without affecting the land quality (paddy / Banana / Coconut cultivation).This produce a green environment and avoid air pollution in this urban areas ${ }^{[9,10]}$. Another selection area is in Rail transport, which is a survey of running a train with emission of carbon particle or not in various places like Madurai Railway station situated in an urban area and few specific places (Dindigul railway station and Chennai railway station) from the year 1951.The Indian railway done a wonderful job of gauge conversion and electrification of rail track in India for past few years. The Railway stations are Madurai Junction, Dindigul Junction and Chennai Egmore station in Tamilnadu, India.

\section{Experimental Procedures}

For composting method, we use the available animal waste which was collected from my own firm, is dumped near the pit for 2-days and mixed thoroughly by manual method. The mixture consist of (cow dung + sheep dung + goat dung + saw dust + banana tree waste + coconut tree waste(leaf only + river sand $(200 \mathrm{~kg})$ in the ratio of $[1: 1: 0.5: 0.1: 0.1: 1])$. The pit is filled with soil and cow dung mixture is laid down/filled layer-by-layer arrangement. The water is sprayed in the pit one or two times only to wet the inner layer of the pit in the first stage of period following within a range of (15-30) days. This will very much helpful to multiply microorganism in large numbers (which is freely available in air), to destroy saw dust and cow dung mixture. In second half period, the microorganism is died and this process needed not any water further for composting. Finally it is converted into natural fertilizer.

\section{(a) Anaerobic Composting Method Applied and Data Observation}

1. The size of the pit Created for composting is: (5' 3" Ft. $\times 3 \mathrm{Ft} . \times 3 \mathrm{ft}$.) in two numbers.

2. A foot step like structure with $\left(15^{\circ}-20^{\circ}\right)$ slop on its face is created inside the pit.

3. Around 3-Nos. of steps $(\mathrm{min})$ may be created with height size of $(3 / 4 \mathrm{ft})$ from one side $(R)$. The actual size is in $\left(3 X 1 X^{3 / 4}\right) \mathrm{ft} 3$ with $20^{\circ}$ slope on its front side, to avoid water logging.

4. The procedure for first pit filling is applicable to another pit also.

5. First step is, the pit is filled with locally available soil, as base layer of size ( $3 / 4 \mathrm{Ft}$.) height.

6 . The second layer is formed on the first layer which consist of thoroughly mixed mixer of [(1)saw dust $+(2)$ cow dung +(3) sheep dung + (4)banana tree waste (leaf+ stem+flower $+(5)$ ground nut husk+ (6)small amount of rice straw by cutting into small piece by a wood cutting machine) $+(7)$ small amount of coconut tree waste (tree leaf only ) and (8) River sand in the ratio of [1:1:0.5:0.1: $0.1: 1]$

7. The third layer is filled with again of soft soil of height ( $3 / 4$ feet).

8. The fourth layer is filled with cow dung sample mixer.

9. The fifth layer is filled with soft soil or mud as final layer

10. The pit is covered with plastic sheet to avoid any heavy rain water penetration inside.

11. The pit is allowed to freely for (5-6) months, to convert into a natural fertilizer.

12. The temperature is taken and recorded before starting of the experiment $\left(\mathrm{T} 1=28^{\circ} \mathrm{C}\right.$ and $\mathrm{T} 2=30^{\circ} \mathrm{C}$ ) in both pits. Similarly final temperature also recorded at the end of process after (5-6) months (T1, T2).

13. Two / three times the water is sprayed on the pit to maintain the moisture level inside.

14. The moisture is needed for microbes to live and increase in large numbers without any help. This is the dominant factor to destroy the samples.

15. A plastic pipe of 3-inch pipe (Second pit only) with hole on the peripheral is inserted in one pit in (3-4) numbers for aeration for few days (1-10). After that it will be removed and filled with river sand only. It gives more aeration and increase of microorganism in short period.

16. The maximum temperature observed in the pits is between $(60-75){ }^{\circ} \mathrm{C}$-after 2 months.

17. The final product will be obtained within (5-6) months from Pit-P1 and (4-5) months from Pit- P2.

18. The constant temperature $(\mathrm{T} 1, \mathrm{~T} 2)$ available in the pits $[\mathrm{P} 1, \mathrm{P} 2]$ are an indication of process completion and ready for use this final product in the agricultural land. 


\section{(b) Aerobic Compositing Method}

In the aerobic composting method, we have to introduce some sort of rotator /agitator is used to turn thoroughly in the first stage of (1-30) days. Totally (3-4) months are required for conversion into natural fertilizer. This method takes only (3-4) months.

\section{$\mathbf{P}^{\mathrm{H}}$ value in Pit-P1 and Pit- $\mathbf{P 2}$}

The previous studies indicate that there is slight variation in $\mathrm{P}^{\mathrm{H}}$ value during entire process (Lakshmi Priya et al., 2010). The $\mathrm{P}^{\mathrm{H}}$ value is recorded before process starting and also recorded in the final day of process. It is found that the $\mathrm{P}^{\mathrm{H}}$ value during the process may also vary from one value to another. In the calculation of $\mathrm{P}^{\mathrm{H}}$ value in a pit is that, sample and water is taken in the ratio of 1:10 (diluted of sample) and shaken well for (10-20) minutes for pit P1 and $\mathrm{P} 2$. The filtered liquid is collected in a beaker, and inserts the $\mathrm{P}^{\mathrm{H}}$ meter to see its value. The value indicated by the Digital $\mathrm{P}^{\mathrm{H}}$ meter are taken as initial levels $(6.2$ \&7.1) for $\mathrm{P} 1$ and $\mathrm{P} 2$. After the specified time is over, it is recommended for taking final reading through this meter. The final $\mathrm{PH}$ value is taken after 150/160 days and $\mathrm{P}^{\mathrm{H}}$ values are observed and recorded as $(6.6$ \& 7.5) for $\mathrm{P} 1$ and $\mathrm{P} 2$ respectively. From the above readings, we come to the conclusion that, the $\mathrm{P}^{\mathrm{H}}$ value is increased when the days are increased.

Figure 01: Temperature Curve of pit-1 and pit-2

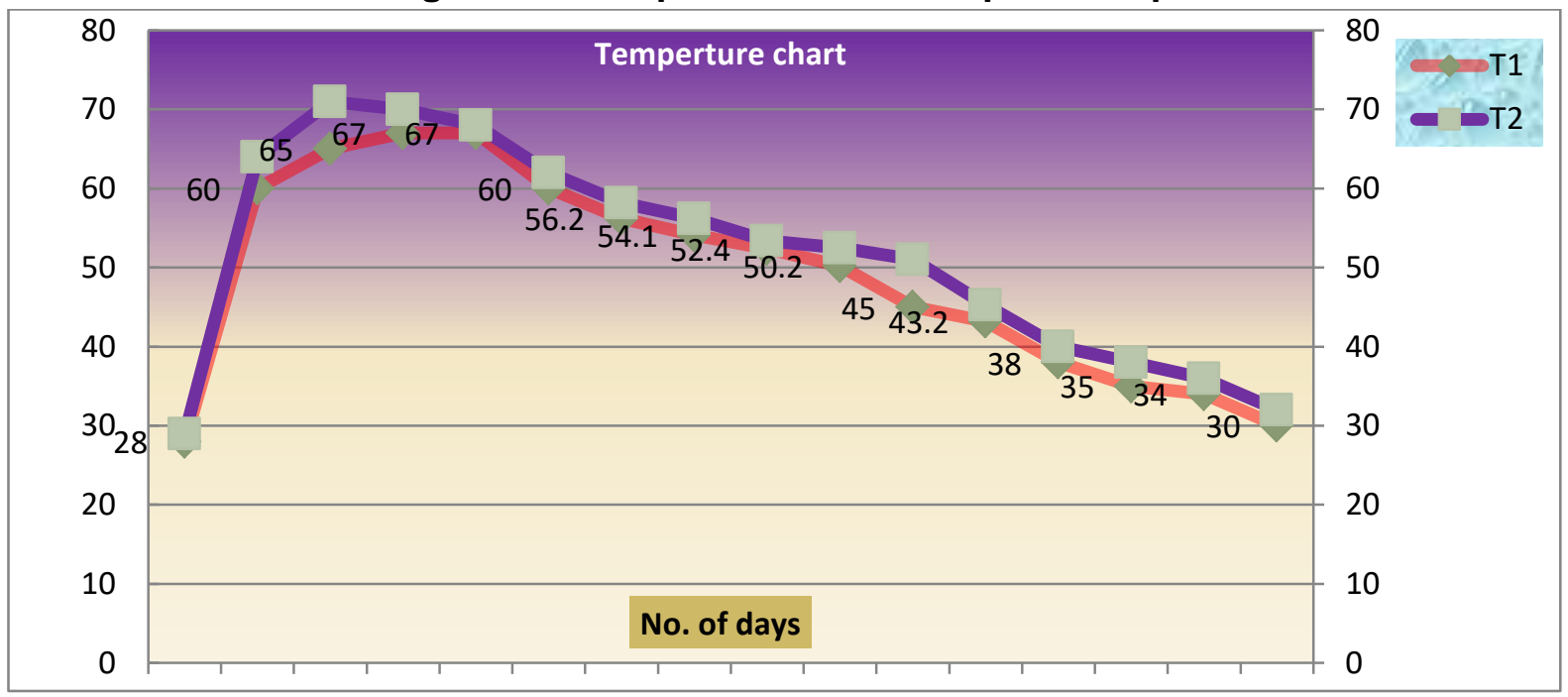

\section{Production Saw Dust and Disposal}

The saw dust or wood dust is produced during the cutting of timber in the saw mill. Which is the end product of timber cutting process ${ }^{[11,12]}$. The saw dust machine has a driving motor running with long circular and triangular saw teeth blade with capacity of (5-HP). The cutting machine consist of two types - in saw mills are a) vertical cutting type and b) horizontal cutting type. The saw dust are ejected from blade with high speed and settle down by its own weight . In vertical type machine, a pit is available below the machine of size $(4 \times 4) \mathrm{ft}^{2}$ in the underground. But in the Horizontal cutting machine, the Saw dust collected, one side of a machine(left/right) with some wooden like obstruction is made vertically as a cover of size $(10 \times 10) \mathrm{ft}^{2}$. There is no top cover for that arrangement. Under the Gravitational force it is settled down slowly. In both cutting types, dust would spread and travel in the air for some distance. During my survey, I found that, all the machines inside the saw mill should handle by the trained people only. So, the machine operator should wear safety dress compulsory - animal skin belt to handle timber on its chest, gloves for hands, goggles for eyes, pants for legs and shoes for his legs. The machine operators are working in dangerous air pollution areas. During my interview, the working people (machine operator) in the saw mill, saying that, we are working in all type of 
climatic conditions with less salary. In our olden ages they may be affected by asthma like diseases and skin allergies. Also they are saying that the air pollution is less in winter season due humidity variation in the atmosphere. During summer and high wind season it is difficult to work and air pollution is more around these areas ${ }^{[13,14]}$. Annually around (8-10) tones of saw dust may be released by a saw mill approximately. The saw dust consist of $\mathrm{CO}, \mathrm{NO}, \mathrm{CO}_{2}, \mathrm{NO}_{2}$, SO2, $\mathrm{H}_{2} \mathrm{~S}$ and $\mathrm{CH}_{4}$

Normally fine wood dust mixed in air and travel around the cutting area even long distance also. It can travel to some other place during high wind speed and air flow direction. Next, the secondary storage of saw dust is dumped in open place, with help of dumping machine vehicles (JCB). More and more dumping of saw dust in one place inside the saw mill would create a pyramid like structure. Formation of such structure would create air turbulence and produce additional air pollution inside the saw mill. So, I found that during my visit in various saw mills, the wind velocity is one of the dominant factors, for saw dust particle move around the mill in all the time. During the rainy season, the saw dust is located in the same place. Excess of rainy water would create bad small inside the saw mill. It also affects the local ground water. Sometimes it would be think that, the high cost lands in urban areas are wasted by this type of waste dumping activity inside the saw mill. The pellet type saw dusts are used for energy generation purposes. The vermi-composting is another method to convert the saw dust in a useful fertilizer for agriculture usages ${ }^{[15,16]}$.

\section{Implements of Additional Design in Saw m/c to Control Dust Pollution}

Addition of cyclone type arrangement in the saw machine itself would help the dust to settle quickly and manual bag fitting to collect waste and dispose very quickly in Lorry / heavy duty goods vehicle.

\section{Application}

1. It is mixed with cow dung to form a pellet, used for cooking fuel in the house

2. It is used for filling a road side pit.

3. It is also used for agricultural fertilizer(composting method)

4. It is also used in Energy Industry and Manufacturing Industries.

5. The air is purified in particular location is maintained as per Who standard ${ }^{[17]}$.

The time taken for conversion of saw dust into natural fertilizer is only few months, and it is completely converted in to a natural fertilizer which is highly suitable for an agriculture land.

\section{Railway and Zero Emission Carbon (Zero Air Pollution)}

The Indian Railways has a long history in India. It is longest rail path in India. A common man can easily travel through train from Kanyakumari to Kashmir with low cost. In china the railways is run by private-public partnership ${ }^{[18,19]}$. It is also implemented in Indian railways for the past 5 years as pilot scheme. The electrification of Railway in difference counties were started and going to be completed in advanced countries ${ }^{[20,21]}$. The utilization coal and diesel are most dominant fuel used to run the rail engine in last 50 years around the world ${ }^{[22,23]}$. The Indian railway is the only largest electrified rail network in India and also Asia. During survey, the various Railways stations in Tamil Nadu, India are taking into account and also travel in all train routes by different types of trains [Stream Engine, Diesel Engine, Electric Train (EMU) in urban/suburban areas] to collect more data. During my data collection/survey, the author observed that 100 percent pollution free conversion of Diesel Engine to electrical operated-EMU in India.

\section{The advantage of Electric train in daily usage}

1. Pollution free environment (100 percent)

2. Running by EMU- creates eco-friendly zones

3. Noise pollution free running (98 percent) 
Table 01: Name of the Railway Station/Junction Taken For My Survey

\begin{tabular}{|c|c|c|}
\hline State & Survey of working Electric track-Rly. station & EMU-UNIT \\
\hline Tamil Nadu & $\begin{array}{ll}\text { 1. Dindigul Jn. } & \text { 2. Madurai Jn., } \\
\text { 3. Tirunelveli Jn. } & \text { 4. Rameswaram Jn. } \\
\text { 5. Kanyakumari Jn. } & \end{array}$ & $\begin{array}{l}\text { 8.Chennai central -Arakkonam, } \\
\text { 9.Chennai-Beach-Thambaram, } \\
\text { 10. Chennai Central- Gummidipoondi }\end{array}$ \\
\hline Maharastra & 6.Mumbai- CST(Victoria terminus) station & 11.Dahanu Rd-Mumbai CST- Colaba \\
\hline Kerela & 7.Tiruvananthapuram station & \\
\hline
\end{tabular}

Within one year (2021) the Indian Railway in the world reaches the target of "net zero carbon emission zone" (Indian railways/core). It also very much helpful to human beings and the wildanimals lived in their native without any migration.

\section{RESULT AND DISCUSSION \\ Composting Technique Adaptation}

The same size of rectangle pits in 2- numbers were trenched and taken for this experimental study. The two sizes of pits are treated in two different ways. One of the pits is under natural treatment (without any PVC pipe insertion). The temperature obtained in the first pit is noted / recorded as temperature $\mathrm{T} 1^{\circ} \mathrm{C}$. Another pit is treated with air supply for some time (<30 days) through 3-inch PVC pipe. The temperature obtained in the second pit is recorded as temperature $\mathrm{T} 2{ }^{\circ} \mathrm{C}$. First step, to start this process, record the temperature reading $(\mathrm{T} 1, \mathrm{~T} 2)$ in both pits and $\mathrm{PH}(1,2)$ values are noted. After that soil layer and (cow dung and saw dust mixture) sample layers are filled alternatively one on the other of $3 / 4$ feet heights respectively. Every 15 days the temperatures T1, T2 are recorded for each pit. We find that, there is difference in temperature readings, due to decomposing rate are vary in each pit. One pit is treated under Anaerobic composting method and another with Aerobic composting method. The maximum temperature reached by both pits are (P1-T1, P2-T2), depends upon the air received by each pit from outside. So P2 is reaching high temperature at faster rate as compare to pit $\mathrm{P} 1$. The time taken to reach the maximum temperature $\left(65-75^{\circ} \mathrm{C}\right)$ by each pit is only between (20-35) days. Periodic water supply to each pit gives increase life time of micro-organism life period. After (30-40) days all microorganism will be destroyed. After that anaerobic treatment is continued and temperature inside each pit gradually decreased when the days are increased. After (4-5) months it is completely converted in to natural fertilizer. The final temperature is approximately equal to atmospheric temperature. There is less in few degrees may be due to seasonal local land temperature influences. The final product does not have any temperature variation, which gives an indication of end of process and it is ready to use as a fertilizer to agricultural land.

\section{Railway Track Electrification Growth Details}

The airport available in India is limited as compared with Railway Networks ${ }^{[24]}$. The Indian central government established a -Central Organization for Railway Electrification" in the year 19 February 1951 at Allahabad to monitor railway electrification conversion process in India. Before Independence the length of rail track electrification may be laid down around $380 \mathrm{~km}$. (1951-52) and at present this tracks are also utilized by Indian Railway ${ }^{[25,26]}$. Every 5-year plan, the Indian railway electrification target was fixed and work was carried out/extended against the target value. Last year $2018-19$, it is extended up to $35,000 \mathrm{~km}$. out of $65,000 \mathrm{KM}$. of total track length in India. So far track electrification completed in percentage is nearly 90percent against total length. This process is continuously extended to create a "pollution free environment", that

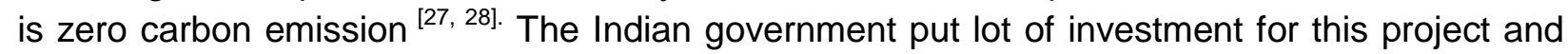
also gives their top priority to electrification of tracks in India. For my paper, the author has am taken, 5-year plan target completed from [ $9^{\text {th }}$ to $13^{\text {th }}$ plan] are consider-for tabulation and chart were drawn (core-Indian railway-2019). The Railway track Electrification work completed in various 5-year plans is given below: 16,000 km. (1997-2002) 17,000 km. (2002-07), 22,000 km. 
(2007-12) 30,000 km. (2012-17) and 35,000 km. (2017-22) respectively. The Modern Indian railway will be converted, 100percent Electric track operation within the year 2023 (2022-23).

Figure 02: Railway Track Electrification in Different states as on 02.01 .2019 in India

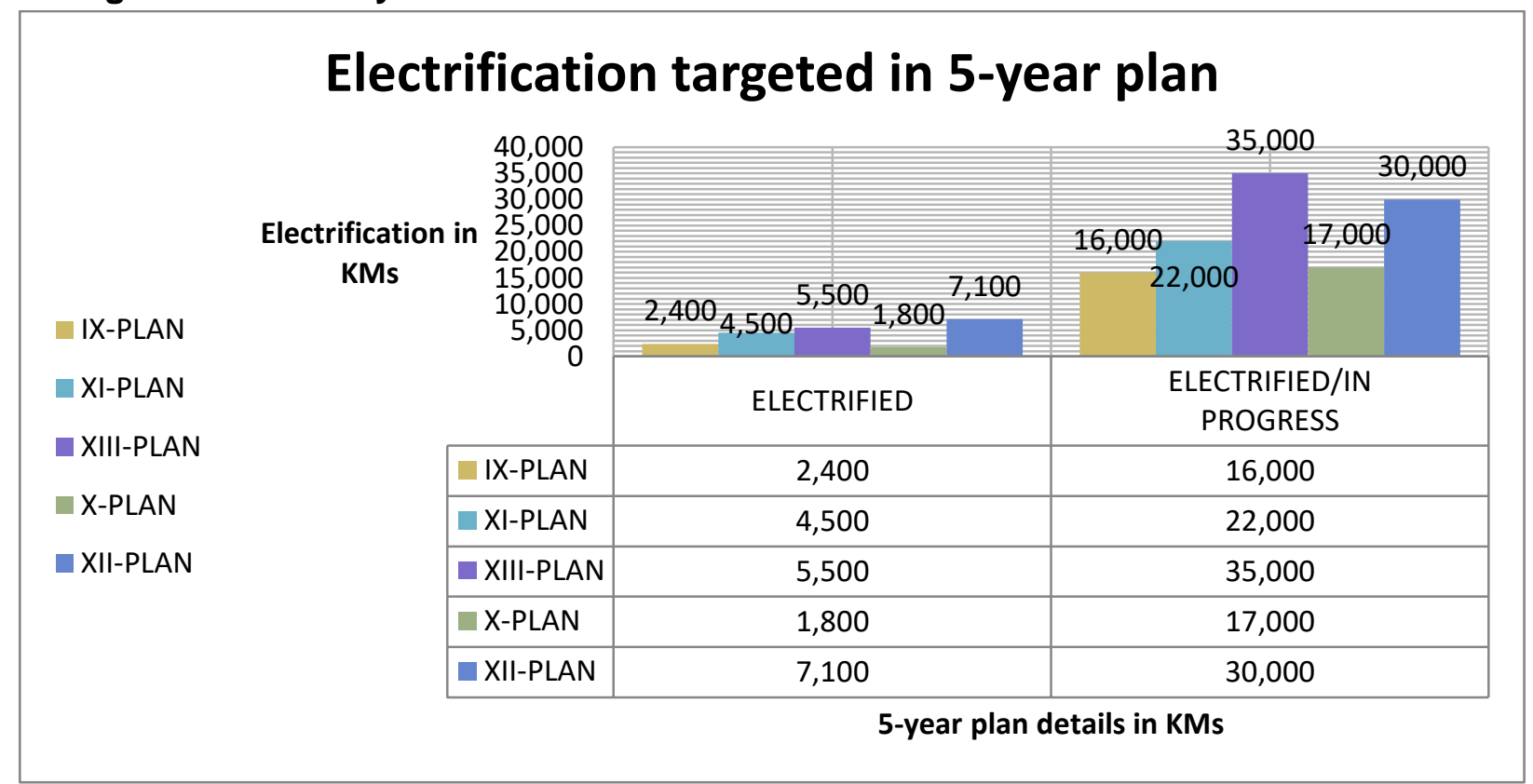

\section{Recommendations}

In general Rice straw, banana tree waste and saw dusts are burning in open ground. It creates more air pollution. In year January 2020, Delhi city in India is more affected by rice/wheat straw burning in open ground in particular period of time in the state of Punjab and U.P. So, the government motivates the farmers to avoid open burning and adopt the composting method of recycling the cow dung, saw dust and other waste. Like Indian Railway Electrification, the road transport also adopts a new- techniques in cars and motor vehicle running under battery would reduce air pollution further. Now in India this process is not an attractive one or in the initial stage only. Further motivation is required among the people and subsides may be increased further, for new battery car/ motor vehicles purchase.

\section{Conclusion}

The village solid waste of obtained in the form of cow dung, saw waste, banana waste and coconut waste are completely possible to convert into (100 percent) natural fertilizer using compost method. By using natural fertilizer cultivation yields 20 percent increases in the banana and paddy cultivation. The air pollution is completely reduced. It is very useful for coconut tree, nursery garden and house garden also. It is the best choice to adopt it in future cultivation. To obtain a great goal, each farmer should motivate further in India. It is the only way to regain our land again and again. Diary firm also used these methods for low cost conversion process with less number of workers. Also, I find that, the possibility of 100 percent emission free zone is possible by all railway tracks should converted in to electrified rail tracks. This electrification is completely done within one year and zero emission of carbon to atmosphere is ensured by Indian Railway in India. This supports reduction of air pollution in India and global warming.

\section{Acknowledgement}

The author is very much thankful to my guide Dr. B. Vijay Bhaskar, Department of Bio Energy, School of Energy and Environmental Science, Madurai Kamaraj University, Madurai, Tamil $\mathrm{Nadu}$, India to give a valuable suggestion to complete this paper as a valuable one and also helping to publish in a journal. 


\section{References}

1. Kadi, A. S. and K. P. Nelavigi, (2015). "Growth of urbanization in India", The International journal of Science \& Technology, vol 3, issue 7, PP.34-35

2. Adegoke, C.O. and Mohammed, T.I, (2002). Investigation of Sawdust Briquettes as High Grade fuels. The West Indian Journal of Engineering, PP.1-5

3. Beulah Gnana Ananthi G. and Partheeban, P. (2001). Solid Waste management, proceedings of ENVIRO 2001, National conference on control of Industrial pollution and Environmental Degradation, PSG college of Technology, Coimbatore, India, PP.375-380

4. Jacob Mayowa Owoyemi, Habeeb Olawale Zakariya, Isa Olalekan Elegbede, Sustainable wood waste management in Nigeria, PP.1-1

5. Lakshmi Priya Thyagarajan, Meenambai, T., Mangaleshwaran, Lakshminarasimaiah, L., and Ramesh, N.S, (2010). Recycling of Pulp and Paper Industry Sludge with Saw Dust by Aerobic Composting Method, Journal of Nature Environment and pollution Technology, Vol.9, No.1, PP.149

6. Okedere O.B., Fakinle B.S., Sonibare J.A., Elehinafe F.B., and Adesina O.A., (2017). Particulate matter pollution from open burning of sawdust in Southwestern Nigeria, vol.3: PP.1-11

7. Ogunbode, B. Fabunmi, F.O., Ibrahim, S.M., Jimoh, I O., \& Idowu O. (2013). Management of Sawmill Wastes in Nigeria; Case study of Minna, Niger state, Greener Journal of Science, Engineering and Technology Research,vol:3,PP.25-30

8. Oluoti, K., Megwai, G., Pettersson, A., \& Richards, T. (2014). Nigeria wood waste: A Dependable renewable fuel option for power production, World journal of Engineering and Technology, vol 2,PP. 230-240

9. Pallav Purohit, Markus Amanan et.al, Mitigation pathways towards national ambient air quality standards in India

10. Pat-Mbano Edith, C. \& N Kwocha Edmund. E, (2015). Assessment of the impact of sawmill industry on ambient air quality at utu community in Akwa-lbom state Nigeria, PP. 1-1

11. Ramasamy. G, Ratnasingam. J, Bakar ES, Halis. R, Muttiah (2015). Assessment of environmental emission from saw milling activity in Malaysia, Bio Resources vol.10, PP. 1-5

12. Rominiyi OL, Adaramola BA, Ikumapayi OM, Oginni OT, Akinola S.A., (2017). Potential Utilization of Sawdust in Energy, Manufacturing and Agricultural Industry Waste to Wealth, Scientific world journal, Vol.5, PP. 526-539

13. Rus. R.M., Daud... A, Musa. K. L, Naing. L. (2008). Knowledge, attitude and practice of sawmill workers, towards noise-induced hearing loss in Kota Bharu, Kelantan, Malays Journal of Medical science, PP.1-5

14. Shankar Adhikari, Barbara Ozarska, (2018). Minimizing Environmental Impacts of Timber products Through the Production Process-“From Sawmill to Final Products”, 2018(Review), PP. 1-15

15. Sakthivel Vellaikkannu, Rajeshwari Duraikannu, Vinoth Mohan, Saralabai Viswanathan Chathlingathe, (2018). Vermicomposting of Saw dust mixed with cow dung using Eudrilus Eugeniae, Volume3; Issue 3; July 2018; PP. 30-32

16. The Ministry of Agriculture and Farmer's welfare - Agro production and waste of vegetable garbage produce air pollution in India, PP: 1-2

17. The World Health Organization (2019). publication on air quality standard released in year, PP: 1-3

18. Anand Kumar Choudhary, Srinivas Rao, (2018). History of Rail Transportation and Importance of Indian Railways (IR) Transportation, International journal of Engineering Development and Research, Vol 6, Issue 3, PP.1-5

19. Chang .Z. (2013). Public-private partnerships in china policy, vol.30(2013),PP.150-160

20. Chitresh Shrivastva, Railway Electrification in India-An Assessment Christ (Deemed to be University)- PP.3-8

21. Gillespie, A.J., and Hayes, H.I (2003). "Railway electrification in American Engineering and maintenance of way Association (AREMA), Practical guide to railway engineering. PP.1-5

22. Indian Railways Transport_ Diesel and Electric motor Unit (EMU)operation in India (central organization for Railway electrification.), PP.2-3

23. Kamboj, P. and R. Tongia (2018). Indian railways and coal: An unsustainable interdependency, retrieved from: www.brookings.edu/research/indian-railways- and -coal- PP.1-5

24. Ministry of civil aviation (India) (2018). "UDAN to promote regional connectivity ", retrieved from: An unsustainable interdependency, retrieved from: www.pib.nic.in/ new site- release id=153739, PP.1-3

25. Pillai, G. (2018). The Role of Rail for India's Development Objectives, Retrieved from : www.iea.org/media/worshop/24 September presentation on Railway workshop/ Grishpillai.pdf.PP.1-5

26. Pradhan, Praveen (2018). "Railway Electrification", stacking facts in favour."In Rail Business analysis".PP.1-5

27. U.S. Environment protection Agency (2009). Report on Emission factors for locomotives,PP.1-3

28. Fathy El-Sayeed Al-Tony and Abdelkader Lashine, Cost-benefit analysis of railway electrification : case study for Cario-Alexandria railway Line, PP.3-4 